\title{
Dendritic cell-based vaccine efficacy: aiming for hot spots
}

\author{
Gabriela Andrea Pizzurro and María Marcela Barrio* \\ Centro de Investigaciones Oncológicas - Fundación Cáncer (CIO - FUCA), Buenos Aires, Argentina
}

\section{Edited by:}

Brian J. Czerniecki, University of Pennsylvania, USA

\section{Reviewed by:}

Urszula Krzych, Walter Reed Army Institute of Research, USA

Sylvie Fournel, Strasbourg University,

France

\section{*Correspondence:}

María Marcela Barrio, Centro de Investigaciones Oncológicas Fundación Cáncer, Crámer 1180, Buenos Aires 1426, Argentina e-mail: barrio.marcela@gmail.com
Many approaches for cancer immunotherapy have targeted dendritic cells (DCs), directly or indirectly, for the induction of antitumor immune responses. DC-based vaccines have been developed using a wide variety of ex vivo DC culture conditions, antigen (Ag) source and loading strategies, maturation agents, and routes of vaccination. Adjuvants are used to activate innate immune cells at the vaccine injection site, to promote Ag transport to the draining lymph nodes (LNs) and to model adaptive immune responses. Despite years of effort, the effective induction of strong and durable antitumor T-cell responses in vaccinated patients remains a challenge. The study of vaccine interactions with other immune cells in the LNs and, more recently, in the injection site has opened new doors for understanding antitumor effectorT-cell licensing and function. In this review, we will briefly discuss the relevant sites and up-to-date facts regarding possible targets for antitumor vaccine refinement. We will focus on the processes taking place at the injection site, adjuvant combinations and their role in DC-based vaccines, LN homing, and modeling vaccine-induced immune responses capable of controlling tumor growth and generating immune memory.

Keywords: immunotherapy, cancer vaccines, dendritic cells, vaccine injection site, draining lymph nodes, antitumor T cells

\section{INTRODUCTION}

Therapeutic cancer vaccines are the focus of active investigation and testing, fueled by their promise as a tool for cancer treatment. In contrast to other cytotoxic therapies, cancer vaccines have demonstrated minimal toxicity in clinical trials to date and have showed some positive results, including slowed tumor growth rates and improved overall survival, but no substantial reductions in tumor burden or improvement in relapse-free $\operatorname{survival}(1,2)$. Dendritic cells (DCs) are professional antigen (Ag)-presenting cells (APCs) that, upon activation, can initiate and direct Ag-specific immune responses. DCs have become a promising tool for cancer immunotherapy due to considerable advances related to their biology and their role in T-cell activation, which has clearly opened avenues for the development of vastly improved clinical protocols (3). Roads are currently leading to: (a) the optimization of DC vaccines to elicit strong and long-lived Ag-specific cluster differentiation $(\mathrm{CD}) 8^{+}$and $\mathrm{CD} 4^{+}$T-cell immunity to control early stage disease and (b) the development of strategies that combine highly immunogenic DC-based vaccines and immunomodulatory antibodies for advanced disease, both of which enhance the potency of beneficial immune arms and offset immunoregulatory pathways $(4,5)$. Cancer vaccination efforts are centered on

\footnotetext{
Abbreviations: Ag, antigen; APC, antigen-presenting cell; CCR7, chemokine receptor 7; CD, cluster differentiation; CTLA, cytotoxic T-lymphocyte-associated protein; DC, dendritic cells; GM-CSF, granulocyte-macrophage colony-stimulating factor; ICOS-L, inducible T-cell costimulator ligand; i.d., intradermal; IFA, incomplete Freund's adjuvant; IFN, interferon; IL, interleukin; LN, lymph node; NK, natural killer; MDSC, myeloid-derived suppressor cells; MHC, major histocompatibility complex; MIP, macrophage inflammatory protein; MMP, metalloproteinase; PBMC, peripheral blood mononuclear cells; PD, programed death; s.c., subcutaneous; Teff, effector T cell; TGF, transforming growth factor; Th, T helper; TLR, toll-like receptor; TNF, tumor necrosis factor; Treg, regulatory $\mathrm{T}$ cell.
}

the disruption of the tolerogenic state of the immune system and direction of an effector T-cell (Teff) response, ultimately leading to cancer regression. This latter point remains a significant challenge when it comes to an objective beneficial outcome in patients. Several questions remain open on the true relevancy of DC-based vaccination in the clinic and the lessons learned over years of clinical investigation $(3,6,7)$. Despite their complexity, models reflecting experimental results have tried to simplify the system to test immunotherapy treatment protocols with in silico simulations of vaccine efficacy (8). However, in addition to multiple parameters in vaccine design, intrinsic variables present in individual patients may equally influence the elicited immune response. Here, we will briefly discuss the main critical stages where immune response can be modulated, and the different factors affecting DC-based strategies, which have been obtained in recent years from basic studies of murine and human DCT-cell interactions, animal models, and human preclinical and clinical studies.

\section{DC-BASED VACCINES: CURRENT APPROACHES}

The application of ex vivo-educated DCs emerged in an effort to avoid possible interferences in therapeutic efficacy due to the dysfunction of endogenous DCs commonly observed in cancer patients (9-11). Ex vivo DCs are mainly generated through in vitro differentiation of peripheral blood mononuclear cells (PBMCs) in the presence of granulocyte-macrophage colonystimulating factor (GM-CSF) and interleukin (IL)-4 or IL-13 (12). DC-based vaccines should present a "mature" state in order to activate an Ag-specific immune response upon T-cell encounter. This differentiated state is characterized by the expression of several costimulatory molecules, the necessary activating second signal in the immunological synapse (13). They include 
CD80 and CD86, CD40, CD70, or inducible T-cell costimulator ligand (ICOS-L) molecules, which interact with their counterparts CD28, CD40L, CD27, and ICOS, respectively, expressed by $\mathrm{T}$ cells. In addition, DCs have elevated levels of Ag-presenting molecules, i.e., major histocompatibility complex (MHC) class I, MHC class II, and CD1 molecules. An immunostimulatory cytokine profile is also required to trigger an efficient $\mathrm{CD}^{+} \mathrm{T}$ cell response, currently considered as the "third signal" $(9,14)$. This process is accompanied by an augmented chemokine-driven migratory capacity, with increased chemokine receptor 7 (CCR7) expression, which favors lymph node (LN) homing and T-cell encounter and allows Ag presentation and T-cell activation (15). This complex context has required the exploration of various strategies (16). A "standard" maturation cocktail, comprised of tumor necrosis factor (TNF)- $\alpha$, IL-1 $\beta$, IL-6, and prostaglandin E2 (17) has been extensively used to develop conventional DCs. This "standard" mature DCs acquire an activated phenotype, respond to LN homing signals, and secrete moderate amounts of T helper (Th)1 cytokine IL-12p70, but with low immunoregulatory cytokine production (17). Targeting the innate danger signal pathway of toll-like receptors (TLRs) improved migration, cytokine profiles, and immune responses (18-20). Alternative tracks use type-1 polarized DCs, generated in the presence of interferon (IFN) $-\gamma$, which show a mature state with IL-12p70 release, chemotactical response to the $\mathrm{LN}$ homing chemokine CCL19, and generate Ag-specific Teff $(21,22)$. "Fast DCs," which are generated in a 3-day culture, show similar performances (23, 24). Taken together, considerable progress has been made over the years, although the potential impact of ex vivo-generated DCs on immunotherapy requires additional studies to be fully disclosed.

The production of ex vivo-generated DCs for personalized vaccines is associated with several inconveniences. The timeconsuming vaccine preparation and elevated costs of production have led to the study of alternative, but related strategies. In vivo DC activation and Ag loading are an interesting approach, as it by-passes the ex vivo DC vaccine drawbacks and may combine the benefits of the physiological environment, making selective use of all the DC subsets present in the dermis and epidermis (25-28). Some targeted and non-targeted vaccines are poorly immunogenic when applied alone. The addition of adjuvants has generated a more favorable environment with viable and motile cells available to initiate a successful immune response, rather than an inflamed Ag depot (29). Many adjuvants currently under evaluation as constituents of cancer vaccines proved to be more than mere delivery systems. Mineral salts, emulsions, and liposomes were able to trigger B-cell and Th1- or Th2-polarizing immune responses. Immunostimulant adjuvants, like TLR-ligands, cytokines, saponins, and bacterial exotoxins, have components that directly interact with the immune system to intensify the elicited response. These events are reviewed in detail by Dubensky and Reed (30). Due to high side effect and toxicity risks with relative low benefit, increased regulatory standards have imposed several barriers for the approval of new adjuvants that must be overcome to meet the increasing demand.

\section{VACCINE ADMINISTRATION: IMMUNE ROLE FOR THE INJECTION SITE}

The route of DC-based vaccine administration remains a matter of debate. Maintaining DC viability and maturation status while eliciting a T-cell response can be difficult due to technical and/or budget limitations $(31,32)$. Direct Ag delivery to DC through selective targeting using monoclonal antibodies against endocytic receptors, such as the C-type lectin receptor DEC205, results in 100 -fold more efficient $\mathrm{CD} 4{ }^{+}$and $\mathrm{CD}^{+}$T-cell activation than fluid-phase or solute pinocytosis $(33,34)$. However, DC-targeted vaccines must be timely combined with adjuvants in order to avoid Ag-specific tolerance (35). Targeting the skin either with ex vivo-loaded DCs or in vivo DC-based strategies has improved immune responses. Local delivery of cell-associated Ag showed delayed T-cell cross-priming, but a more robust, polyfunctional, effector response (36). Likewise, intradermal (i.d.) administration induces a more potent and long-lasting specific, functional $\mathrm{CD}^{+} \mathrm{T}$-cell response that effectively breaks self-tolerance in mice (37) and provides a superior functional tumor Ag-specific reaction in delayed-type hypersensitivity sites after DC vaccination in melanoma patients (32). The skin offers a rich immune network comprised of Langerhans cells in the epidermal compartment and dermal DCs. Local APC are accompanied by specialized cells with immune function, including macrophages, keratinocytes, mast cells, natural killer (NK) T cells, and fibroblasts, with access to draining lymphatic and blood vessels (27). These features turn the skin into an ideal niche for DC-based vaccination, so far extensively explored in mice $(25,38)$ and in in vitro human cell cultures (39), although little is known about human APC function in situ. Microneedle arrays are a new vaccine delivery system that can enter the skin at a very low insertion force and controlled depth, facilitating i.d. vaccine administration in simultaneous proximal inoculations (40). The microneedles offer a dose-sparing advantage, improved safety, and patient compliance, and therefore stand firm as an effective, easy delivery route with a great future in vaccination (41). Polymeric, water-soluble microneedles dissolve and release nanoencapsulated $\mathrm{Ag}$ into skin tissue, with no residual waste. In mice, skin-derived DCs delivered nanoparticles to draining LNs, subsequently inducing a potent activation of specific $\mathrm{CD}^{+}$and $\mathrm{CD}^{+}{ }^{+} \mathrm{T}$ cells (42); however, the study did not make comparisons to traditional Ag delivery systems.

The natural skin micromilieu should not be underestimated when choosing the vaccine injection site, as it may influence the elicited immune response, especially with respect to tumor localization $(43,44)$. Keratinocytes may also be involved in local APC inflammatory activation through the secretion of the active form of IL-1 $\beta$, as well as in suppressive imprinting through transforming growth factor (TGF)- $\beta 1$ production. Therefore, the immunological balance within the newly formed structure at the site of DC-based vaccine injection, observed both in mice (45) and humans (46), must be delicately studied. One study reports that repeated vaccination with melanoma peptides in incomplete Freund's adjuvant (IFA) induced organized and persistent lymphoid aggregates in the patients' dermis. They contained separate $\mathrm{B}$ - and T-cell areas, with proliferating $\mathrm{CD} 4^{+}$and $\mathrm{CD}^{+}$ $\mathrm{T}$ cells, as well as $\mathrm{CD}^{+}{ }^{+}$FoxP3 ${ }^{+}$lymphocytes, mature DC, high 
endothelial venule-like vessels, and lymphoid chemokines (46). Though Ag persistence at the vaccination site produces a delayed, but stronger Teff response (36), the long-persistent peptide depots with IFA induce tumor-specific $\mathrm{CD} 8^{+} \mathrm{T}$ cells that remain locally sequestered, dysfunctional, and eventually deleted, rather than redistributing into the tumor, resulting in hyporesponsiveness to subsequent vaccination (29). Biomaterials may overcome these limitations, as short-lived formulations like hydrogels can provide a niche that allows in situ priming and immune modulation while preserving cell viability, thus enhancing the efficacy of next-generation immunotherapy $(47,48)$.

The recruitment of APC to the injection site and subsequent local activation is a thoroughly explored strategy. Different chemoattractants such as GM-CSF and chemokines have been used as adjuvants in the clinical setting (49), with occasionally unexpected results. Conditioning the injection site with macrophage inflammatory protein (MIP)-3 $\alpha$-expressing irradiated cells prior to DC vaccination effectively suppresses B16F1 melanoma growth in animals (50). However, co-expression of MIP- $1 \alpha$ nullified the GM-CSF-induced immune response against the GL261 glioma, rather than attracting T cells to GM-CSFstimulated DC (51). TLR-ligands are added to vaccine formulations to avoid Ag-specific tolerance, i.e., when targeting DEC205 (35), and to further stimulate cells of the innate immune system, thereby increasing the potency of the elicited immune response (52). Their ability to skew the response toward a Th1 or Th2 profile, generating different Ag-specific Teff to regulatory T cell (Treg) ratios, is the main parameter evaluated, and differs according to vaccine setting. Some TLR2/4, TLR3, and TLR9 ligands, like Bacillus Calmette-Guerin, polyinosinic:polycytidylic acid, and CpG oligodeoxynucleotides respectively, are currently being studied in DC-based cancer immunotherapy with combinatorial positive results $(19,53-55)$, while the TLR7 ligand imiquimod and lipid mediators such as QuilA or ISCOM produce more varied results $(53,54,56-58)$.

\section{DRAINING LN: DC MIGRATION AND THE ACTIVATION OF T CELLS}

After vaccine administration, activated DC must closely interact with naïve $\mathrm{T}$ cells, which, upon Ag recognition, exert their cytotoxic, helper, or regulatory function. The $\mathrm{LN}$ is a multifunctional and compartmentalized organ that collectively offers structural guidance for optimal Ag-loaded DC proximity to, and scanning of a large number of $\mathrm{T}$ cells $(59,60)$. Apart from the events controlling DC migration from the skin toward, into, and within the lymphatic vessels (61), recent advances in multiphoton-based time-lapse and intravital microscopy have provided insight into the complex migratory behavior and interactions of DCs and T cells within the lymphoid microenvironment, mainly in mice. Activated DCs typically arrive at the draining LN between 24 and $72 \mathrm{~h}$ after injection, but it can be as soon as $2 \mathrm{~h}$ after stimulation (62). DCs vigorously extend long, agile dendrites, thus promoting the scanning of a vast, autonomously moving T-cell repertoire. $\mathrm{CD}^{+}$and $\mathrm{CD}^{+} \mathrm{T}$ cells have different $\mathrm{Ag}$ surveillance strategies, presenting asymmetric roles for MHC interactions and LN transit times $(63,64)$. Ag-bearing DCs are highly efficient recruiters of peptide-specific $\mathrm{T}$ cells, in part through the secretion of chemokines. The resulting overall avidity of the interaction influences the probability that $\mathrm{T}$ cells are stably captured by DCs $(65,66)$. Chemokines present in the LN structure promote DC interaction with cognate $\mathrm{CD} 4^{+}$and $\mathrm{CD}^{+}{ }^{+}$naïve $\mathrm{T}$ cells $(59,67)$ that, once activated, leave the LN to exert their function. Taken together, these complex cellular behaviors promote proper Ag presentation in the LN and the potential efficient systemic antitumor $\mathrm{CD} 8^{+} \mathrm{T}$-cell response.

The efficiency of DC migration to the LNs has been related to their maturation state (68) as well as to the expression of CCR7, which confers additional attributes to mature DC, such as migratory speed and inhibition of apoptosis $(69,70)$. Again, the route of administration has great influence over both DC migration and activated T-cell LN homing, and therefore may improve clinical outcome, as seen in mice (31). When choosing i.d. or subcutaneous (s.c.) inoculation, the manipulation of either the injection site or the DCs themselves can stimulate DC migration. As mentioned before, conditioning of the injection site can activate resident APC and generate a more immunogenic environment and more permeable lymphatic vessels with increased secretion of the CCR7-ligand CCL21 (71, 72). DC mobilization can be improved through metalloproteinase (MMP) secretion and changing the adhesion molecule profile $(73,74)$. In mice, increasing the number of injected DCs has shown improved migration efficacy. CCR7 ${ }^{+}$DCs efficiently induce a rapid increase in LN cellularity, observed before the onset of T-cell proliferation. The elicited $\mathrm{CD} 4^{+} \mathrm{T}$-cell response is proportional to the number of Ag-carrying DCs reaching the LN (71). In patients, decreasing the number of injected DCs actually improves the proportion of cells migrating to the LNs, but the analysis is limited by the detection method (75). Today, the number of Ag-loaded DCs required at the $\mathrm{LN}$ to mount a complete antitumor response is unknown.

Maximizing LN homing of DC-based vaccines may enhance antitumor responses (76), therefore techniques for the clinical assessment of DC migration have been perfected, including fluorescent-, ${ }^{111}$ Indium-, and magnetic particle-labeling for cell tracking $(77,78)$. But, more importantly, DCs must not only reach one or multiple secondary lymphoid tissues, but also enter the T-cell-rich areas in order to efficiently elicit an antitumor $\mathrm{CD}^{+}$ response that may contribute to a better clinical outcome. Furthermore, following the vaccination of tumor-bearing mice, high tumor-specific Teff to specific Treg ratios in draining LN were associated with enhanced $\mathrm{CD} 8^{+}$T-cell infiltration and durable rejection of tumors (53). The normal immunological function of regional tumor-draining LN is compromised through immunosuppressive mechanisms (79) and the presence of metastases, though they remain a rich source of sensitized $\mathrm{T}$ cells $(43,80$, 81). FoxP3 ${ }^{+} \mathrm{T}$ cells induce the death of DCs and impede normal motility and the cross-priming of $\mathrm{CD}^{+} \mathrm{T}$ cells (82). Spatial organization of DCs within the tumor-draining LNs impacts the duration of disease-free survival in breast cancer patients, where the number and size of DC clusters were associated with DC maturation status and T-cell co-localization and interaction (83). Therefore, knowing which DC subsets are present in LNs and their role in T-cell activation (84), it is possible to specifically target therapies to break the tolerogenic environment. Combinatorial 
approaches may include the use of adjuvants or cytokines (81, 85) as well as other cells expressing costimulatory molecules or functioning as helpers, such as NK cells $(58,86-88)$.

\section{EFFECTOR ANTITUMOR IMMUNE RESPONSES: BREAKING THE ICE}

The efficacy of antitumor therapy mainly depends on four critical components: the elicited $\mathrm{CD} 8^{+}$Teffs, the quality of the $\mathrm{CD}^{+}$ helper $\mathrm{T}$ cells, the elimination and/or non-activation of Tregs, and the breakdown of the immunosuppressive tumor microenvironment (3). Therapeutic vaccination is currently designed as an adjuvant or neoadjuvant treatment for patients with a high risk of recurrence. Adequate vaccine design and a better understanding of host-tumor interactions are needed to overcome systemic and local immune tolerance and generate an effective antitumor response (2). There are several essential steps in vaccine formulation that collectively impact the immune response and ultimately the clinical outcome. Vaccine design must consider the administration route (36), the type and amount of Ag provided (89-92), the delivery system (93), and the addition of different immunostimulants that lead to in vivo activation of $\mathrm{CD}^{+} \mathrm{T}$ cells $(53,58)$ as well as long-term memory (54). Favorable clinical responses require a Th1 immune profile, and furthermore, a high vaccine Ag-specific Teff to Treg ratio was predictive of clinical benefit (94). Along with $\mathrm{CD}^{+}{ }^{-}$Teffs, $\mathrm{CD} 4^{+}$ $\mathrm{T}$ cells strongly influence the elicited antitumor response. Agloaded DCs can induce human $\mathrm{CD} 4^{+}$T-cell proliferation that combined with strong activating signals, overcome immunosuppression through Th17 differentiation (95). In mice, CD4 ${ }^{+} \mathrm{T}$ cells generate increased numbers of tumor-specific effector and memory $\mathrm{CD}^{+} \mathrm{T}$ cells. The role of $\mathrm{CD}^{+} \mathrm{T}$ cells is critical in the early stages of the immune response, helping reduce $\mathrm{CD}^{+}$ T-cell exhaustion by decreasing expression of the immunoinhibitory receptor programed death (PD)-1 (96). However, selective $\mathrm{CD}^{+}{ }^{+} \mathrm{T}$-cell tolerance underlies ineffective vaccination. Vaccinemediated naïve T-cell priming is inhibited due to a minor but distinct population of tumor-reactive $\mathrm{CD} 4^{+} \mathrm{T}$ cells, generated in the tumor-draining LNs and systemically redistributed (97). Higher numbers of administered DCs revert this effect, allowing $\mathrm{CD}^{+}{ }^{+} \mathrm{T}$-cell priming comparable to tumor-free mice (97). Incorporating $\mathrm{CD}^{+}$T-cell epitopes from foreign Ags into vaccines reconstitute $\mathrm{CD} 4^{+}$T-cell help, reactivating the latent functional capacity of Ag-specific $\mathrm{CD}^{+} \mathrm{T}$ - and B-cell pools with durable antitumor immunity (98). In melanoma patients, coactivating Ag-specific CD4 ${ }^{+}$T cells with $\mathrm{MHC}-\mathrm{I} / \mathrm{II}$ peptide-loaded DCs augments Ag-specific $\mathrm{CD}^{+}{ }^{+} \mathrm{T}$-cell responses, which contributes to improved clinical responses, as compared to dacarbazine-treated control patients (99).

Measuring the frequency of IFN- $\gamma$-secreting $\mathrm{CD}^{+} \mathrm{T}$ cells is insufficient to evaluate the quality of vaccine-elicited immunity (3). The localization of CD8 ${ }^{+}$Teff impacts their phenotype and function. Melanoma-infiltrating $\mathrm{CD}^{+}$Teffs express higher levels of PD-1 and cytotoxic T-lymphocyte-associated protein (CTLA)4 , both associated with T-cell exhaustion, than their counterparts in normal tissues and circulating blood (100). The tumor microenvironment exhibits several immunosuppressive factors, reviewed in Vasaturo et al. (101) that neutralize tumor-specific
T cells and hamper DC vaccination efficacy. Along with myeloidderived suppressor cells (MDSC), Tregs directly suppress CD8 ${ }^{+}$ Teff responses at the tumor site. Increased numbers of MDSCs and Tregs are also found in the metastatic $\mathrm{LN}$ and peripheral blood of patients (102). Studies in mice have demonstrated a superior suppressive capacity in Ag-specific Tregs than polyclonal Tregs. Melanoma patients display a broad repertoire of circulating tumor Ag-specific Tregs that are not detected in healthy individuals (103). The use of HClO-oxidized tumor lysate for DC loading reduced circulating Tregs and serum IL-10 while eliciting a potent Teff response against ovarian tumor Ags, as compared to standard Ag preparation methods (104). Adjuvants can determine the Th response profile as well as the generation of MDSC and Tregs (53, 56). Vaccine antitumor effects can be improved substantially with combination therapy since it allows a simultaneous counterattack on multiple tumor evasion mechanisms. Radiation therapy modifies both the phenotype and the microenvironment of tumor cells, but requires $\mathrm{CD} 8^{+} \mathrm{T}$ cells to achieve a therapeutic effect. Further combination with Th1 cell therapy augmented the generation of infiltrating Teff and induced a complete regression of tumors in mice (105). Treg depletion helped induce protective antitumor immunity and the generation of immunological memory after s.c. peptide immunization (55). Blockade of PD-1 enhanced breast cancer vaccine efficacy by altering both the $\mathrm{CD} 8^{+} \mathrm{T}$-cell and $\mathrm{DC}$ components of the tumor microenvironment (106). Peptides combined with a single low dose of cyclophosphamide reduced the number of Tregs in renal cell cancer patients (107). Nevertheless, combinatorial therapies must be carefully designed and tested due to possible increased toxicity, autoimmunity, or opposite effects, e.g., the systemic coadministration of IL-2 alongside DC vaccination resulted in higher Treg frequencies in peripheral blood and invariant Ag-specific Teff response (32).

\section{CONCLUDING REMARISS}

There is no clear consensus for a "DC vaccine recipe" that would provide a better performance in terms of disease control. There are as many possible components for vaccine formulation as variations in vaccination scheme design. However, integrating an optimized vaccine preparation with a local immune activation seems to be the future of treatment platforms (Figure 1). There is a push for new immunomonitoring parameters, since assessment of relevant immune responses following DC-based vaccination remains a true pitfall. Events occurring in the tumor microenvironment are not accessible or are even invisible in undetected micrometastases. Traditional monitoring of peripheral blood immune response does not correlate with clinical outcome of therapeutic vaccines. Over the past decade, the increased knowledge of DC biology and crucial mechanisms involved in the generation of the immune response provided valuable tools to improve DC-based vaccines and position them as a potentially curative strategy for cancer patients. The discovery of molecular targets and blocking antibodies for immune checkpoints has opened new avenues for combination therapy with DC-based vaccines. In the near future, cancer immunology researchers face the challenge of integrating all of the knowledge and advances to design rational and efficient DC-based vaccine treatments to achieve long-term clinical response. 


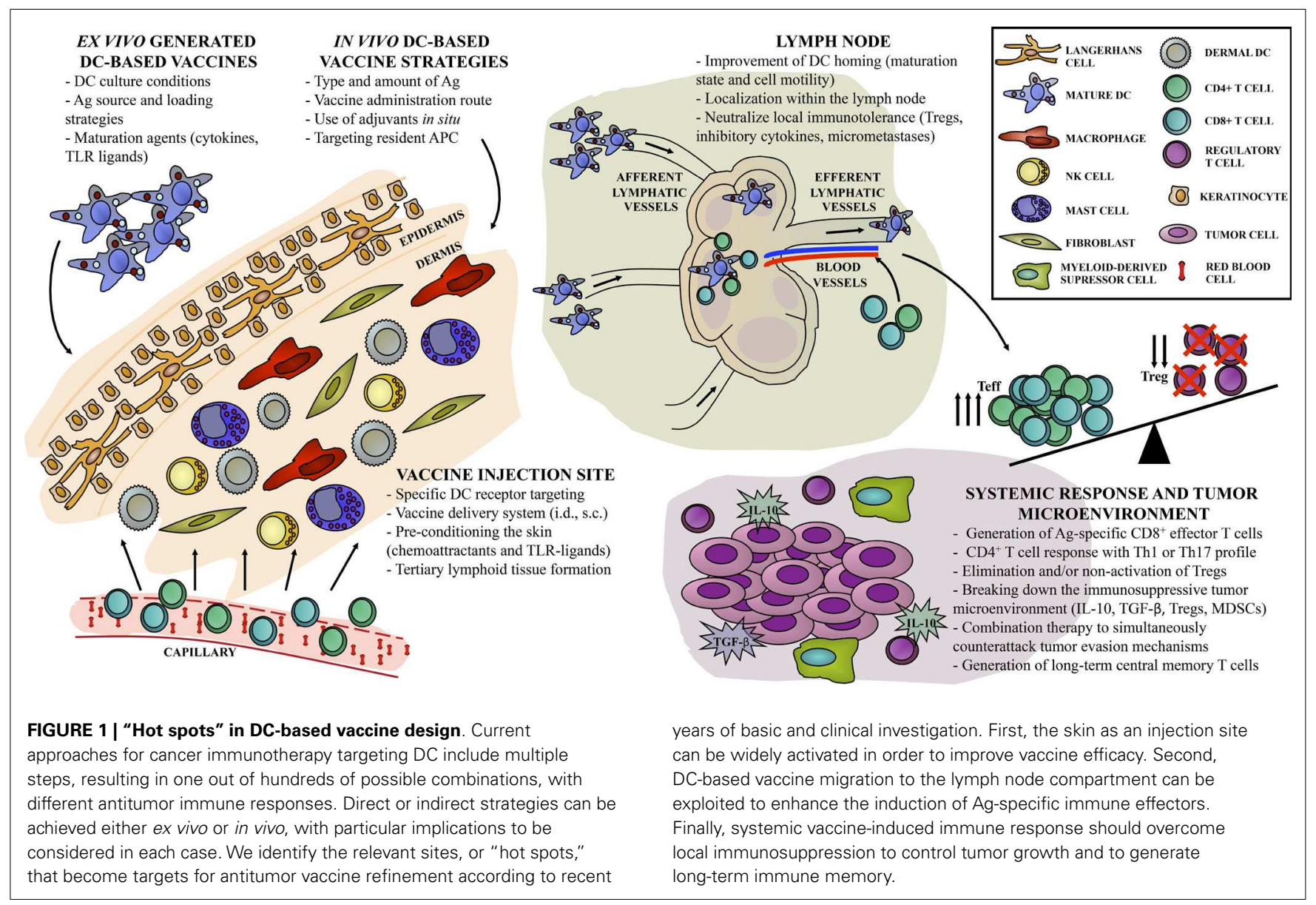

\section{ACKNOWLEDGMENTS}

This work was supported by funds from Agencia Nacional de Promoción Científica y Tecnológica (ANPCyT); Instituto Nacional del Cáncer (INC); Fundación Cáncer (FUCA); Fundación Sales and Fundación Mosoteguy, Argentina. MB is a member of Consejo Nacional de Investigaciones Científicas y Técnicas (CONICET), Argentina. GP is a fellow from the same institution. We would like to thank Mrs. María Luisa Pollack from the Instituto Alexander Fleming Library for her kind assistance.

\section{REFERENCES}

1. Madan RA, Gulley JL, Fojo T, Dahut WL. Therapeutic cancer vaccines in prostate cancer: the paradox of improved survival without changes in time to progression. Oncologist (2010) 15(9):969-75. doi:10.1634/ theoncologist.2010-0129

2. Guo C, Manjili MH, Subjeck JR, Sarkar D, Fisher PB, Wang XY. Therapeutic cancer vaccines: past, present, and future. Adv Cancer Res (2013) 119:421-75. doi:10.1016/B978-0-12-407190-2.00007-1

3. Palucka K, Ueno H, Roberts L, Fay J, Banchereau J. Dendritic cells: are they clinically relevant? Cancer J (2010) 16(4):318-24. doi:10.1097/PPO. 0b013e3181eaca83

4. Palucka K, Banchereau J. Dendritic-cell-based therapeutic cancer vaccines. Immunity (2013) 39(1):38-48. doi:10.1016/j.immuni.2013.07.004

5. Chen DS, Mellman I. Oncology meets immunology: the cancer-immunity cycle. Immunity (2013) 39(1):1-10. doi:10.1016/j.immuni.2013.07.012

6. Butterfield LH. Dendritic cells in cancer immunotherapy clinical trials: are we making progress? Front Immunol (2013) 4:454. doi:10.3389/fimmu. 2013.00454

7. Galluzzi L, Senovilla L, Vacchelli E, Eggermont A, Fridman WH, Galon J, et al. Trial watch: dendritic cell-based interventions for cancer therapy. Oncoimmunology (2012) 1(7):1111-34. doi:10.4161/onci.21494

8. Depillis L, Gallegos A, Radunskaya A. A model of dendritic cell therapy for melanoma. Front Oncol (2013) 3:56. doi:10.3389/fonc.2013.00056

9. Kalinski P, Edington H, Zeh HJ, Okada H, Butterfield LH, Kirkwood JM, et al. Dendritic cells in cancer immunotherapy: vaccines or autologous transplants? Immunol Res (2011) 50(2-3):235-47. doi:10.1007/s12026-011-8224-z

10. Pinzon-Charry A, Maxwell T, Lopez JA. Dendritic cell dysfunction in cancer: a mechanism for immunosuppression. Immunol Cell Biol (2005) 83(5):451-61. doi:10.1111/j.1440-1711.2005.01371.x

11. Herber DL, Cao W, Nefedova Y, Novitskiy SV, Nagaraj S, Tyurin VA, et al. Lipid accumulation and dendritic cell dysfunction in cancer. Nat Med (2010) 16(8):880-6. doi:10.1038/nm.2172

12. Alters SE, Gadea JR, Holm B, Lebkowski J, Philip R. IL-13 can substitute for IL-4 in the generation of dendritic cells for the induction of cytotoxic T lymphocytes and gene therapy. J Immunother (1999) 22(3):229-36. doi:10.1097/00002371-199905000-00005

13. Reichardt P, Dornbach B, Gunzer M. APC, T cells, and the immune synapse. Curr Top Microbiol Immunol (2010) 340:229-49. doi:10.1007/978-3-64203858-7_12

14. Linette GP, Carreno BM. Dendritic cell-based vaccines: shining the spotlight on signal 3. Oncoimmunology (2013) 2(11):e26512. doi:10.4161/onci.26512

15. Delamarre L, Mellman I. Harnessing dendritic cells for immunotherapy. Semin Immunol (2011) 23(1):2-11. doi:10.1016/j.smim.2011.02.001

16. Frankenberger B, Schendel DJ. Third generation dendritic cell vaccines for tumor immunotherapy. Eur J Cell Biol (2012) 91(1):53-8. doi:10.1016/j.ejcb. 2011.01.012

17. Jonuleit H, Kuhn U, Muller G, Steinbrink K, Paragnik L, Schmitt E, et al. Pro-inflammatory cytokines and prostaglandins induce maturation of potent 
immunostimulatory dendritic cells under fetal calf serum-free conditions. Eur J Immunol (1997) 27(12):3135-42. doi:10.1002/eji.1830271209

18. Boullart AC, Aarntzen EH, Verdijk P, Jacobs JF, Schuurhuis DH, BenitezRibas D, et al. Maturation of monocyte-derived dendritic cells with toll-like receptor 3 and 7/8 ligands combined with prostaglandin E2 results in high interleukin-12 production and cell migration. Cancer Immunol Immunother (2008) 57(11):1589-97. doi:10.1007/s00262-008-0489-2

19. Marongiu L, Donini M, Toffali L, Zenaro E, Dusi S. ESAT-6 and HspX improve the effectiveness of BCG to induce human dendritic cells-dependent Th1 and NK cells activation. PLoS One (2013) 8(10):e75684. doi:10.1371/journal.pone. 0075684

20. Sheng KC, Day S, Wright MD, Stojanovska L, Apostolopoulos V. Enhanced dendritic cell-mediated antigen-specific CD4+ T cell responses: IFN-gamma aids TLR stimulation. J Drug Deliv (2013) 2013:516749. doi:10.1155/2013/516749

21. Mailliard RB, Wankowicz-Kalinska A, Cai Q, Wesa A, Hilkens CM, Kapsenberg ML, et al. Alpha-type-1 polarized dendritic cells: a novel immunization tool with optimized CTL-inducing activity. Cancer Res (2004) 64(17):5934-7. doi:10.1158/0008-5472.CAN-04-1261

22. Hansen M, Met O, Svane IM, Andersen MH. Cellular based cancer vaccines: type 1 polarization of dendritic cells. Curr Med Chem (2012) 19(25):4239-46. doi:10.2174/092986712802884213

23. Dauer M, Obermaier B, Herten J, Haerle C, Pohl K, Rothenfusser S, et al. Mature dendritic cells derived from human monocytes within 48 hours: a novel strategy for dendritic cell differentiation from blood precursors. J Immunol (2003) 170(8):4069-76. doi:10.4049/jimmunol.170.8.4069

24. Spranger S, Javorovic M, Burdek M, Wilde S, Mosetter B, Tippmer S, et al. Generation of Th1-polarizing dendritic cells using the TLR7/8 agonist CL075. J Immunol (2010) 185(1):738-47. doi:10.4049/jimmunol.1000060

25. Sparber F, Tripp CH, Hermann M, Romani N, Stoitzner P. Langerhans cells and dermal dendritic cells capture protein antigens in the skin: possible targets for vaccination through the skin. Immunobiology (2010) 215(9-10):770-9. doi:10.1016/j.imbio.2010.05.014

26. Palucka K, Banchereau J, Mellman I. Designing vaccines based on biology of human dendritic cell subsets. Immunity (2010) 33(4):464-78. doi:10.1016/j. immuni.2010.10.007

27. Fehres CM, Garcia-Vallejo JJ, Unger WW, van Kooyk Y. Skin-resident antigenpresenting cells: instruction manual for vaccine development. Front Immunol (2013) 4:157. doi:10.3389/fimmu.2013.00157

28. Cohn L, Delamarre L. Dendritic cell-targeted vaccines. Front Immunol (2014) 5:255. doi:10.3389/fimmu.2014.00255

29. Hailemichael Y, Dai Z, Jaffarzad N, Ye Y, Medina MA, Huang XF, et al. Persistent antigen at vaccination sites induces tumor-specific $\mathrm{CD} 8(+) \mathrm{T}$ cell sequestration, dysfunction and deletion. Nat Med (2013) 19(4):465-72. doi:10.1038/nm.3105

30. Dubensky TW Jr, Reed SG. Adjuvants for cancer vaccines. Semin Immunol (2010) 22(3):155-61. doi:10.1016/j.smim.2010.04.007

31. Mullins DW, Sheasley SL, Ream RM, Bullock TN, Fu YX, Engelhard VH. Route of immunization with peptide-pulsed dendritic cells controls the distribution of memory and effector $\mathrm{T}$ cells in lymphoid tissues and determines the pattern of regional tumor control. J Exp Med (2003) 198(7):1023-34. doi:10.1084/jem.20021348

32. Lesterhuis WJ, de Vries IJ, Schreibelt G, Lambeck AJ, Aarntzen EH, Jacobs JF, et al. Route of administration modulates the induction of dendritic cell vaccine-induced antigen-specific $\mathrm{T}$ cells in advanced melanoma patients. Clin Cancer Res (2011) 17(17):5725-35. doi:10.1158/1078-0432.CCR-11- 1261

33. Mahnke K, Guo M, Lee S, Sepulveda H, Swain SL, Nussenzweig M, et al. The dendritic cell receptor for endocytosis, DEC-205, can recycle and enhance antigen presentation via major histocompatibility complex class II-positive lysosomal compartments. J Cell Biol (2000) 151(3):673-84. doi:10.1083/jcb. 151.3.673

34. Bonifaz L, Bonnyay D, Mahnke K, Rivera M, Nussenzweig MC, Steinman RM. Efficient targeting of protein antigen to the dendritic cell receptor DEC-205 in the steady state leads to antigen presentation on major histocompatibility complex class I products and peripheral CD8+ T cell tolerance. $J$ Exp Med (2002) 196(12):1627-38. doi:10.1084/jem.20021598

35. Kreutz M, Giquel B, Hu Q, Abuknesha R, Uematsu S, Akira S, et al. Antibodyantigen-adjuvant conjugates enable co-delivery of antigen and adjuvant to dendritic cells in cis but only have partial targeting specificity. PLoS One (2012) 7(7):e40208. doi:10.1371/journal.pone.0040208
36. Bouvier I, Jusforgues-Saklani H, Lim A, Lemaitre F, Lemercier B, Auriau C, et al. Immunization route dictates cross-priming efficiency and impacts the optimal timing of adjuvant delivery. Front Immunol (2011) 2:71. doi:10.3389/fimmu. 2011.00071

37. Hangalapura BN, Oosterhoff D, Gupta T, de Groot J, Wijnands PG, van Beusechem VW, et al. Delivery route, MyD88 signaling and cross-priming events determine the anti-tumor efficacy of an adenovirus based melanoma vaccine. Vaccine (2011) 29(12):2313-21. doi:10.1016/j.vaccine. 2011.01.022

38. Sen D, Forrest L, Kepler TB, Parker I, Cahalan MD. Selective and site-specific mobilization of dermal dendritic cells and Langerhans cells by Th1- and Th2-polarizing adjuvants. Proc Natl Acad Sci U S A (2010) 107(18):8334-9. doi:10.1073/pnas.0912817107

39. Barrio MM, Abes R, Colombo M, Pizzurro G, Boix C, Roberti MP, et al. Human macrophages and dendritic cells can equally present MART-1 antigen to $\mathrm{CD} 8(+) \mathrm{T}$ cells after phagocytosis of gamma-irradiated melanoma cells. PLoS One (2012) 7(7):e40311. doi:10.1371/journal.pone.0040311

40. Kim YC, Park JH, Prausnitz MR. Microneedles for drug and vaccine delivery. Adv Drug Deliv Rev (2012) 64(14):1547-68. doi:10.1016/j.addr.2012.04.005

41. Suh H, Shin J, Kim YC. Microneedle patches for vaccine delivery. Clin Exp Vaccine Res (2014) 3(1):42-9. doi:10.7774/cevr.2014.3.1.42

42. Zaric M, Lyubomska O, Touzelet O, Poux C, Al-Zahrani S, Fay F, et al. Skin dendritic cell targeting via microneedle arrays laden with antigen-encapsulated poly-D,L-lactide-co-glycolide nanoparticles induces efficient antitumor and antiviral immune responses. ACS Nano (2013) 7(3):2042-55. doi:10.1021/ $\mathrm{nn} 304235 \mathrm{j}$

43. Ohlfest JR, Andersen BM, Litterman AJ, Xia J, Pennell CA, Swier LE, et al. Vaccine injection site matters: qualitative and quantitative defects in CD8 T cells primed as a function of proximity to the tumor in a murine glioma model. J Immunol (2013) 190(2):613-20. doi:10.4049/jimmunol.1201557

44. Lindenberg JJ, Oosterhoff D, Sombroek CC, Lougheed SM, Hooijberg E, Stam AG, et al. IL-10 conditioning of human skin affects the distribution of migratory dendritic cell subsets and functional T cell differentiation. PLoS One (2013) 8(7):e70237. doi:10.1371/journal.pone.0070237

45. Mac Keon S, Gazzaniga S, Mallerman J, Bravo AI, Mordoh J, Wainstok R. Vaccination with dendritic cells charged with apoptotic/necrotic B16 melanoma induces the formation of subcutaneous lymphoid tissue. Vaccine (2010) 28(51):8162-8. doi:10.1016/j.vaccine.2010.09.095

46. Harris RC, Chianese-Bullock KA, Petroni GR, Schaefer JT, Brill LB II, Molhoek $\mathrm{KR}$, et al. The vaccine-site microenvironment induced by injection of incomplete Freund's adjuvant, with or without melanoma peptides. J Immunother (2012) 35(1):78-88. doi:10.1097/CJI.0b013e31823731a4

47. Liu Y, Xiao L, Joo KI, Hu B, Fang J, Wang P. In situ modulation of dendritic cells by injectable thermosensitive hydrogels for cancer vaccines in mice. Biomacromolecules (2014) 15(10):3836-45. doi:10.1021/bm501166j

48. Purwada A, Roy K, Singh A. Engineering vaccines and niches for immune modulation. Acta Biomater (2014) 10(4):1728-40. doi:10.1016/j.actbio.2013.12.036

49. Bobanga ID, Petrosiute A, Huang AY. Chemokines as cancer vaccine adjuvants. Vaccines (Basel) (2013) 1(4):444-62. doi:10.3390/vaccines1040444

50. Shih NY, Yang HY, Cheng HT, Hung YM, Yao YC, Zhu YH, et al. Conditioning vaccination site with irradiated MIP-3alpha-transfected tumor cells enhances efficacy of dendritic cell-based cancer vaccine. J Immunother (2009) 32(4):363-9. doi:10.1097/CJI.0b013e31819d29d8

51. Herrlinger U, Aulwurm S, Strik H, Weit S, Naumann U, Weller M. MIP-1alpha antagonizes the effect of a GM-CSF-enhanced subcutaneous vaccine in a mouse glioma model. J Neurooncol (2004) 66(1-2):147-54. doi:10.1023/B:NEON. 0000013497.04322.fc

52. Gnjatic S, Sawhney NB, Bhardwaj N. Toll-like receptor agonists: are they good adjuvants? Cancer J (2010) 16(4):382-91. doi:10.1097/PPO.0b013e3181eaca65

53. Perret R, Sierro SR, Botelho NK, Corgnac S, Donda A, Romero P. Adjuvants that improve the ratio of antigen-specific effector to regulatory $\mathrm{T}$ cells enhance tumor immunity. Cancer Res (2013) 73(22):6597-608. doi:10.1158/0008-5472. CAN-13-0875

54. Goldinger SM, Dummer R, Baumgaertner P, Mihic-Probst D, Schwarz K, Hammann-Haenni A, et al. Nano-particle vaccination combined with TLR7 and -9 ligands triggers memory and effector CD8(+) T-cell responses in melanoma patients. Eur J Immunol (2012) 42(11):3049-61. doi:10.1002/eji. 201142361 
55. Bright JD, Schultz HN, Byrne JA, Bright RK. Injection site and regulatory T cells influence durable vaccine-induced tumor immunity to an over-expressed self tumor associated antigen. Oncoimmunology (2013) 2(7):e25049. doi:10. 4161/onci.25049

56. Dang Y, Wagner WM, Gad E, Rastetter L, Berger CM, Holt GE, et al. Dendritic cell-activating vaccine adjuvants differ in the ability to elicit antitumor immunity due to an adjuvant-specific induction of immunosuppressive cells. Clin Cancer Res (2012) 18(11):3122-31. doi:10.1158/1078-0432.CCR-12-0113

57. Fehres CM, Bruijns SC, van Beelen AJ, Kalay H, Ambrosini M, Hooijberg E, et al. Topical rather than intradermal application of the TLR7 ligand imiquimod leads to human dermal dendritic cell maturation and CD8+ T-cell crosspriming. Eur J Immunol (2014) 44(8):2415-24. doi:10.1002/eji.201344094

58. Duewell P, Kisser U, Heckelsmiller K, Hoves S, Stoitzner P, Koernig S, et al. ISCOMATRIX adjuvant combines immune activation with antigen delivery to dendritic cells in vivo leading to effective cross-priming of CD8+ T cells. J Immunol (2011) 187(1):55-63. doi:10.4049/jimmunol.1004114

59. Castellino F, Huang AY, Altan-Bonnet G, Stoll S, Scheinecker C, Germain $\mathrm{RN}$. Chemokines enhance immunity by guiding naive CD8+ T cells to sites of CD4+ T cell-dendritic cell interaction. Nature (2006) 440(7086):890-5. doi:10.1038/nature04651

60. Munoz MA, Biro M, Weninger W. T cell migration in intact lymph nodes in vivo. Curr Opin Cell Biol (2014) 30C:17-24. doi:10.1016/j.ceb.2014.05.002

61. Teijeira A, Russo E, Halin C. Taking the lymphatic route: dendritic cell migration to draining lymph nodes. Semin Immunopathol (2014) 36(2):261-74. doi:10.1007/s00281-013-0410-8

62. Grayson MH, Ramos MS, Rohlfing MM, Kitchens R, Wang HD, Gould A, et al. Controls for lung dendritic cell maturation and migration during respiratory viral infection. J Immunol (2007) 179(3):1438-48. doi:10.4049/jimmunol.179. 3.1438

63. Miller MJ, Hejazi AS, Wei SH, Cahalan MD, Parker I. T cell repertoire scanning is promoted by dynamic dendritic cell behavior and random $\mathrm{T}$ cell motility in the lymph node. Proc Natl Acad Sci U S A (2004) 101(4):998-1003. doi:10.1073/pnas.0306407101

64. Mandl JN, Liou R, Klauschen F, Vrisekoop N, Monteiro JP, Yates AJ, et al. Quantification of lymph node transit times reveals differences in antigen surveillance strategies of naive CD4+ and CD8+ T cells. Proc Natl Acad Sci U S A (2012) 109(44):18036-41. doi:10.1073/pnas.1211717109

65. Kaiser A, Donnadieu E, Abastado JP, Trautmann A, Nardin A. CC chemokine ligand 19 secreted by mature dendritic cells increases naive $\mathrm{T}$ cell scanning behavior and their response to rare cognate antigen. J Immunol (2005) 175(4):2349-56. doi:10.4049/jimmunol.175.4.2349

66. Bousso P, Robey E. Dynamics of CD8+ T cell priming by dendritic cells in intact lymph nodes. Nat Immunol (2003) 4(6):579-85. doi:10.1038/ni928

67. Hugues S, Scholer A, Boissonnas A, Nussbaum A, Combadiere C, Amigorena S, et al. Dynamic imaging of chemokine-dependent CD8+ T cell help for CD8+ T cell responses. Nat Immunol (2007) 8(9):921-30. doi:10.1038/ni1495

68. de Vries IJ, Krooshoop DJ, Scharenborg NM, Lesterhuis WJ, Diepstra JH, Van Muijen GN, et al. Effective migration of antigen-pulsed dendritic cells to lymph nodes in melanoma patients is determined by their maturation state. Cancer Res (2003) 63(1):12-7.

69. Sanchez-Sanchez N, Riol-Blanco L, Rodriguez-Fernandez JL. The multiple personalities of the chemokine receptor CCR7 in dendritic cells. J Immunol (2006) 176(9):5153-9. doi:10.4049/jimmunol.176.9.5153

70. Chen YZ, Ruan GX, Yao XL, Li LM, Hu Y, Tabata Y, et al. Co-transfection gene delivery of dendritic cells induced effective lymph node targeting and antitumor vaccination. Pharm Res (2013) 30(6):1502-12. doi:10.1007/s11095013-0985-8

71. MartIn-Fontecha A, Sebastiani S, Hopken UE, Uguccioni M, Lipp M, Lanzavecchia A, et al. Regulation of dendritic cell migration to the draining lymph node: impact on T lymphocyte traffic and priming. J Exp Med (2003) 198(4):615-21. doi:10.1084/jem.20030448

72. Yin X, Johns SC, Kim D, Mikulski Z, Salanga CL, Handel TM, et al. Lymphatic specific disruption in the fine structure of heparan sulfate inhibits dendritic cell traffic and functional T cell responses in the lymph node. J Immunol (2014) 192(5):2133-42. doi:10.4049/jimmunol.1301286

73. Ratzinger G, Stoitzner P, Ebner S, Lutz MB, Layton GT, Rainer C, et al. Matrix metalloproteinases 9 and 2 are necessary for the migration of Langerhans cells and dermal dendritic cells from human and murine skin. J Immunol (2002) 168(9):4361-71. doi:10.4049/jimmunol.168.9.4361
74. Johnson LA, Jackson DG. Control of dendritic cell trafficking in lymphatics by chemokines. Angiogenesis (2014) 17(2):335-45. doi:10.1007/s10456-0139407-0

75. Aarntzen EH, Srinivas M, Bonetto F, Cruz LJ, Verdijk P, Schreibelt G, et al. Targeting of 111 In-labeled dendritic cell human vaccines improved by reducing number of cells. Clin Cancer Res (2013) 19(6):1525-33. doi:10.1158/10780432.CCR-12-1879

76. Verdijk P, Aarntzen EH, Punt CJ, de Vries IJ, Figdor CG. Maximizing dendritic cell migration in cancer immunotherapy. Expert Opin Biol Ther (2008) 8(7):865-74. doi:10.1517/14712598.8.7.865

77. Srinivas M, Aarntzen EH, Bulte JW, Oyen WJ, Heerschap A, de Vries IJ, et al. Imaging of cellular therapies. Adv Drug Deliv Rev (2010) 62(11):1080-93. doi:10.1016/j.addr.2010.08.009

78. Ferguson PM, Slocombe A, Tilley RD, Hermans IF. Using magnetic resonance imaging to evaluate dendritic cell-based vaccination. PLoS One (2013) 8(5):e65318. doi:10.1371/journal.pone.0065318

79. Munn DH, Mellor AL. The tumor-draining lymph node as an immuneprivileged site. Immunol Rev (2006) 213:146-58. doi:10.1111/j.1600-065X. 2006.00444.x

80. Zheng $\mathrm{R}$, Shu S. Immune response to cancer and its regulation in regional lymph nodes. J Surg Oncol (2011) 103(6):550-4. doi:10.1002/jso.21692

81. Jeanbart L, Ballester M, de Titta A, Corthesy P, Romero P, Hubbell JA, et al. Enhancing efficacy of anticancer vaccines by targeted delivery to tumordraining lymph nodes. Cancer Immunol Res (2014) 2(5):436-47. doi:10.1158/ 2326-6066.CIR-14-0019-T

82. Boissonnas A, Scholer-Dahirel A, Simon-Blancal V, Pace L, Valet F, Kissenpfennig A, et al. Foxp3+ T cells induce perforin-dependent dendritic cell death in tumor-draining lymph nodes. Immunity (2010) 32(2):266-78. doi:10.1016/j. immuni.2009.11.015

83. Chang AY, Bhattacharya N, Mu J, Setiadi AF, Carcamo-Cavazos V, Lee GH, et al. Spatial organization of dendritic cells within tumor draining lymph nodes impacts clinical outcome in breast cancer patients. J Transl Med (2013) 11:242. doi:10.1186/1479-5876-11-242

84. van de Ven R, van den Hout MF, Lindenberg JJ, Sluijter BJ, van Leeuwen PA, Lougheed SM, et al. Characterization of four conventional dendritic cell subsets in human skin-draining lymph nodes in relation to T-cell activation. Blood (2011) 118(9):2502-10. doi:10.1182/blood-2011-03-344838

85. St John AL, Chan CY, Staats HF, Leong KW, Abraham SN. Synthetic mast-cell granules as adjuvants to promote and polarize immunity in lymph nodes. Nat Mater (2012) 11(3):250-7. doi:10.1038/nmat3222

86. Higham EM, Wittrup KD, Chen J. Activation of tolerogenic dendritic cells in the tumor draining lymph nodes by CD8+ T cells engineered to express CD40 ligand. J Immunol (2010) 184(7):3394-400. doi:10.4049/jimmunol.0903111

87. Bouwer AL, Saunderson SC, Caldwell FJ, Damani TT, Pelham SJ, Dunn AC, et al. NK cells are required for dendritic cell-based immunotherapy at the time of tumor challenge. J Immunol (2014) 192(5):2514-21. doi:10.4049/jimmunol. 1202797

88. Wong JL, Muthuswamy R, Bartlett DL, Kalinski P. IL-18-based combinatorial adjuvants promote the intranodal production of CCL19 by NK cells and dendritic cells of cancer patients. Oncoimmunology (2013) 2(9):e26245. doi:10.4161/onci.26245

89. Henrickson SE, Perro M, Loughhead SM, Senman B, Stutte S, Quigley M, et al. Antigen availability determines CD8(+) T cell-dendritic cell interaction kinetics and memory fate decisions. Immunity (2013) 39(3):496-507. doi:10.1016/j.immuni.2013.08.034

90. Rosalia RA, Quakkelaar ED, Redeker A, Khan S, Camps M, Drijfhout JW, et al. Dendritic cells process synthetic long peptides better than whole protein, improving antigen presentation and T-cell activation. Eur J Immunol (2013) 43(10):2554-65. doi:10.1002/eji.201343324

91. Wang B, Zaidi N, He LZ, Zhang L, Kuroiwa JM, Keler T, et al. Targeting of the non-mutated tumor antigen HER2/neu to mature dendritic cells induces an integrated immune response that protects against breast cancer in mice. Breast Cancer Res (2012) 14(2):R39. doi:10.1186/bcr3135

92. Pizzurro GA, Madorsky Rowdo FP, Pujol-Lereis LM, Quesada-Allue LA, Copati AM, Roberti MP, et al. High lipid content of irradiated human melanoma cells does not affect cytokine-matured dendritic cell function. Cancer Immunol Immunother (2013) 62(1):3-15. doi:10.1007/s00262-012-1295-4

93. Fox CB, Moutaftsi M, Vergara J, Desbien AL, Nana GI, Vedvick TS, et al. TLR4 ligand formulation causes distinct effects on antigen-specific cell-mediated 
and humoral immune responses. Vaccine (2013) 31(49):5848-55. doi:10.1016/ j.vaccine.2013.09.069

94. Welters MJ, Kenter GG, de Vos van Steenwijk PJ, Lowik MJ, Berends-van der Meer DM, Essahsah F, et al. Success or failure of vaccination for HPV16positive vulvar lesions correlates with kinetics and phenotype of induced T-cell responses. Proc Natl Acad Sci U S A (2010) 107(26):11895-9. doi:10.1073/pnas. 1006500107

95. Valente M, Baey C, Louche P, Dutertre CA, Vimeux L, Maranon C, et al. Apoptotic cell capture by DCs induces unexpectedly robust autologous CD4+ T-cell responses. Eur J Immunol (2014) 44(8):2274-86. doi:10.1002/eji.201344191

96. Church SE, Jensen SM, Antony PA, Restifo NP, Fox BA. Tumor-specific CD4+ $\mathrm{T}$ cells maintain effector and memory tumor-specific CD8+ T cells. Eur J Immunol (2014) 44(1):69-79. doi:10.1002/eji.201343718

97. Schiering C, Guarnerio J, Basso V, Muzio L, Mondino A. Antigen-experienced $\mathrm{CD} 4(+) \mathrm{T}$ cells limit naive T-cell priming in response to therapeutic vaccination in vivo. Cancer Res (2010) 70(15):6161-70. doi:10.1158/0008-5472.CAN09- 4398

98. Snook AE, Magee MS, Schulz S, Waldman SA. Selective antigen-specific $\mathrm{CD} 4(+)$ T-cell, but not CD8(+) T- or B-cell, tolerance corrupts cancer immunotherapy. Eur J Immunol (2014) 44(7):1956-66. doi:10.1002/eji. 201444539

99. Aarntzen EH, De Vries IJ, Lesterhuis WJ, Schuurhuis D, Jacobs JF, Bol K, et al. Targeting CD4(+) T-helper cells improves the induction of antitumor responses in dendritic cell-based vaccination. Cancer Res (2013) 73(1):19-29. doi:10.1158/0008-5472.CAN-12-1127

100. Ahmadzadeh M, Johnson LA, Heemskerk B, Wunderlich JR, Dudley ME, White $\mathrm{DE}$, et al. Tumor antigen-specific CD8 $\mathrm{T}$ cells infiltrating the tumor express high levels of PD-1 and are functionally impaired. Blood (2009) 114(8):1537-44. doi:10.1182/blood-2008-12-195792

101. Vasaturo A, Di Blasio S, Peeters DG, de Koning CC, de Vries JM, Figdor CG, et al. Clinical implications of co-inhibitory molecule expression in the tumor microenvironment for DC vaccination: a game of stop and go. Front Immunol (2013) 4:417. doi:10.3389/fimmu.2013.00417

102. Idorn M, Kollgaard T, Kongsted P, Sengelov L, Thor Straten P. Correlation between frequencies of blood monocytic myeloid-derived suppressor cells, regulatory $\mathrm{T}$ cells and negative prognostic markers in patients with castrationresistant metastatic prostate cancer. Cancer Immunol Immunother (2014) 63(11):1177-87. doi:10.1007/s00262-014-1591-2
103. Vence L, Palucka AK, Fay JW, Ito T, Liu YJ, Banchereau J, et al. Circulating tumor antigen-specific regulatory $\mathrm{T}$ cells in patients with metastatic melanoma. Proc Natl Acad Sci U S A (2007) 104(52):20884-9. doi:10.1073/pnas. 0710557105

104. Chiang CL, Kandalaft LE, Tanyi J, Hagemann AR, Motz GT, Svoronos N, et al. A dendritic cell vaccine pulsed with autologous hypochlorous acid-oxidized ovarian cancer lysate primes effective broad antitumor immunity: from bench to bedside. Clin Cancer Res (2013) 19(17):4801-15. doi:10.1158/1078-0432. CCR-13-1185

105. Takeshima T, Chamoto K, Wakita D, Ohkuri T, Togashi Y, Shirato H, et al. Local radiation therapy inhibits tumor growth through the generation of tumorspecific CTL: its potentiation by combination with Th1 cell therapy. Cancer Res (2010) 70(7):2697-706. doi:10.1158/0008-5472.CAN-09-2982

106. Karyampudi L, Lamichhane P, Scheid AD, Kalli KR, Shreeder B, Krempski JW, et al. Accumulation of memory precursor CD8 $\mathrm{T}$ cells in regressing tumors following combination therapy with vaccine and anti-PD-1 antibody. Cancer Res (2014) 74(11):2974-85. doi:10.1158/0008-5472.CAN-13-2564

107. Walter S, Weinschenk T, Stenzl A, Zdrojowy R, Pluzanska A, Szczylik C, et al. Multipeptide immune response to cancer vaccine IMA901 after single-dose cyclophosphamide associates with longer patient survival. Nat Med (2012) 18(8):1254-61. doi:10.1038/nm.2883

Conflict of Interest Statement: The authors declare that the research was conducted in the absence of any commercial or financial relationships that could be construed as a potential conflict of interest.

Received: 03 December 2014; accepted: 16 February 2015; published online: 03 March 2015.

Citation: Pizzurro GA and Barrio MM (2015) Dendritic cell-based vaccine efficacy: aiming for hot spots. Front. Immunol. 6:91. doi: 10.3389/fimmu.2015.00091

This article was submitted to Immunotherapies and Vaccines, a section of the journal Frontiers in Immunology.

Copyright $\odot 2015$ Pizzurro and Barrio. This is an open-access article distributed under the terms of the Creative Commons Attribution License (CC BY). The use, distribution or reproduction in other forums is permitted, provided the original author(s) or licensor are credited and that the original publication in this journal is cited, in accordance with accepted academic practice. No use, distribution or reproduction is permitted which does not comply with these terms. 